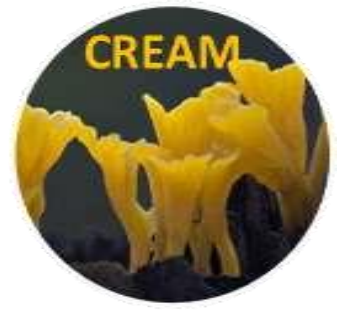

\title{
Doi 10.5943/cream/5/3/2
}

\section{Diversity and anticancer activity of endophytic fungi associated with the medicinal plant Saraca asoca}

\author{
Jinu MV ${ }^{1^{*}}$ and Jayabaskaran $\mathrm{C}^{1}$ \\ ${ }^{1}$ Department of Biochemistry, Indian Institute of Science, Bangalore, India
}

Jinu MV, Jayabaskaran C 2015 - Diversity and anticancer activity of endophytic fungi associated with the medicinal plant Saraca asoca. Current Research in Environmental \& Applied Mycology 5(3), 169-179, Doi 10.5943/cream/5/3/2

\begin{abstract}
Cancer remains a major health issue worldwide due to the high rate of its morbidity and mortality. Search for tumor selective, novel anticancer compounds with lesser side-effects remains a major focus of cancer research. Endophytic fungi, owing to their chemical diversity, are an attractive source of bioactive metabolites. In the present study, we have explored the endophytic fungal population associated with a traditional Indian medicinal plant, Saraca asoca for their cytotoxic potentialities. Taxonomic identities and phylogenetic relationships of the fungal isolates were investigated using molecular techniques. 37 fungal species obtained from $S$. asoca were grouped into 22 genera of which the most dominant genus was Camarosporium followed by Pestalotiopsis and Fusarium. Fermentation extracts of all fungal isolates were assessed for their cytotoxic effects towards three human cancer cell lines, HeLa, HepG2 and PC3. 18 fungi exhibited remarkable cytotoxic activities among which Pestalotiopsis sp. 6 exhibited the most significant cytotoxicity towards all three cell lines used. Apoptosis inducing effect of Pestalotiopsis sp. 6 ethyl acetate culture extract (PS6) on HeLa cell line was further assessed by in vitro assays. PS6 induced mitochondria dependent apoptotic cell death in HeLa cells in a dose dependent manner. The study suggests these fungal extracts to be potential sources of secondary metabolites which can serve as promising lead molecules for the development of novel anti-cancer agents.
\end{abstract}

Key words - Apoptosis - cytotoxicity - secondary metabolites.

\section{Introduction}

Despite the advances made in cancer treatment, the discovery and development of novel anticancer drugs and new treatment strategies still continues due to the limitations of existing drugs such as lack of tumor selectivity, narrow therapeutic index and multidrug resistance of cancer types (Coates et al. 1983, Persidis 1999). Endophytic fungi have become an integral part of modern drug discovery process due to the enormous diversity of chemical compounds they produce (Strobel \& Daisy 2003, Verma et al. 2009). Moreover, endophytic fungi can serve as inexhaustible and economically feasible sources of compounds they produce (Aly et al. 2010). Chemical diversity of endophytic population is largely shaped by the uniqueness of niche they occupy. Hence, endophytic fungi residing in plants restricted to exotic habitats or those with ethnobotanical value are more likely to synthesize unique hoard of novel secondary metabolites. 
Saraca asoca is a traditional Indian medicinal plant, known to have anti-cancer, antimenorrhagic, anti-oxidant, anti-oxytocic and anti-microbial activities (Pradhan et al. 2009). Almost every part of the plant is medicinal and it has been a part of ayurvedic medicine for centuries. The plant has become vulnerable in its natural habitat due to unscientific management practices as well as over exploitation of plant parts by indigenous population. The medicinal value as well as unique geographical distribution of $S$. asoca makes it an ideal host for the isolation of endophytic fungi. The purpose of the present study is to explore the endophytic fungal population associated with $S$. asoca and screen the fungal fermentation extracts for their cytotoxic effects towards human cancer cell lines.

\section{Materials \& Methods}

\section{Isolation of endophytic fungi}

Samples of fresh, healthy, uninfected leaves, stems and bark of $S$. asoca were collected and processed within $5 \mathrm{~h}$ of collection. The collected samples of $S$. asoca were washed thoroughly in running tap water and cut into small square pieces (approximately $5 \mathrm{~mm}^{2}$ ) using sterile scalpel. The samples were surface sterilized with $70 \%$ ethanol for $5 \mathrm{~s}$, sodium hypochlorite for $90 \mathrm{~s}$ and finally washed with sterile distilled water. Surface sterilized samples were blotted dry and placed equidistantly on potato dextrose agar (PDA) medium amended with $100 \mathrm{mg} / \mathrm{L}$ ampicillin. Petridishes were sealed using parafilm and incubated at $25^{\circ} \mathrm{C} \pm 2{ }^{\circ} \mathrm{C}$ in dark. The petridishes were monitored everyday for the growth of endophytic fungal colonies and the growing edges of colonies from the plant segments were subcultured to fresh PDA plates to obtain pure cultures. The fungal isolates were numbered and maintained in PDA slants at $4^{\circ} \mathrm{C}$ or as spores and mycelium in $15 \%(\mathrm{v} / \mathrm{v})$ glycerol at $70^{\circ} \mathrm{C}$.

Colonization frequency ( $\mathrm{CF} \%$ ) of individual endophytic isolates was calculated using the formula $\left(n_{i} / N_{t}\right) X 100$, where $n_{i}$ is the number of segments colonized by each isolate and $N_{t}$ is the total number of segments. These values indicate the prevalence of each taxon in comparison with the total endophytic fungal community within the host plant. Species diversity of the endophytic fungal community was calculated using the Shannon-Weaver index, $H=-\Sigma\left(n_{i} / N\right) \ln \left(n_{i} / N\right)$, where $n_{i}$ is the number of individuals of taxon $\mathrm{i}$ and $\mathrm{N}$ is the total number of individuals.

\section{Characterization of endophytic fungi}

Fungal isolates were identified based on ITS (internal transcribed spacer) sequence analysis. Fungal genomic DNA was used as the template for PCR based amplification of fungal ITS regions (ITS1 and ITS2 regions) using the universal primers: ITS 1 forward primer (TCCGTAGGTGAACCTGCGG) and ITS 4 reverse primer (TCCTCCGCTTATTGATATGC). The PCR conditions used were as follows: initial denaturation at $94^{\circ} \mathrm{C}$ for 4 min followed by 35 cycles of denaturation at $94^{\circ} \mathrm{C}$ for $40 \mathrm{~s}$, annealing at $50^{\circ} \mathrm{C}$ for $50 \mathrm{~s}$ and extension at $72^{\circ} \mathrm{C}$ for $10 \mathrm{~min}$, followed by a final extension at $72^{\circ} \mathrm{C}$ for $10 \mathrm{~min}$. The $50 \mu \mathrm{PCR}$ reaction mixture contained $1 \mathrm{X}$ PCR buffer, $200 \mu \mathrm{M}$ of each dNTP, $1.5 \mathrm{mM} \mathrm{MgCl} 2,10 \mathrm{pM}$ of each primer, $100 \mathrm{ng}$ of genomic DNA and $1 \mathrm{U}$ of Taq DNA polymerase (Genei, Bangalore). The products of PCR amplification were separated on $1 \%$ (w/v) agarose gel in 1X TAE buffer and visualized under UV light after staining the gel with ethidium bromide. A $1 \mathrm{~kb}$ DNA ladder (Invitrogen, USA) was used as size marker. Direct sequencing of the PCR product was performed with primer ITS1 using an ABI Big Dye Terminator cycle sequencing ready reaction kit (Applied Biosystems, USA). Sequence data were aligned and compared with sequences deposited in the GenBank database using GenBank BLASTN and submitted in NCBI Genbank database. Phylogenetic and molecular evolutionary analysis of the fungal isolates was performed based on their ITS sequences using MEGA 6.0 software (Tamura et al. 2013). 


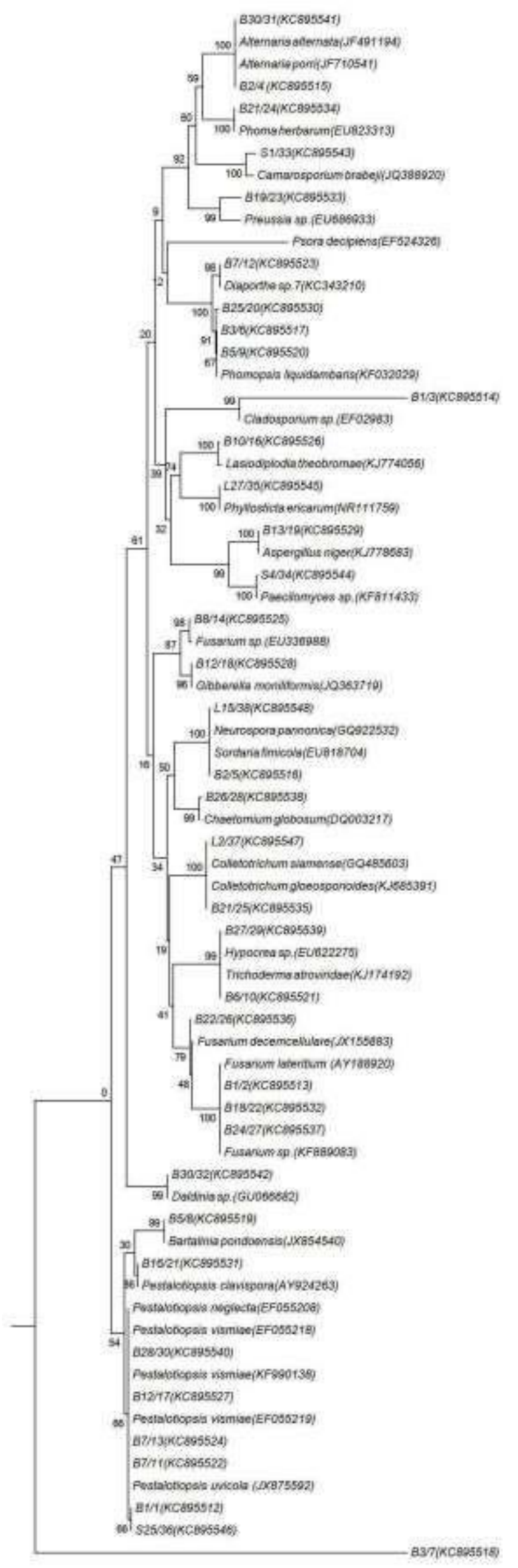

Fig. 1 - Phylogenetic tree of S. asoca endophytic fungal isolates based on ITS and 5.8 S rDNA gene. The tree was produced using Mega 6.0 Neighbour - Joining algorithm. GenBank accession numbers of sequences are indicated in parantheses. Scale bar indicates $20 \%$ estimated sequence divergence. 


\section{Preparation of fungal organic extract}

Each fungal isolate was inoculated in $500 \mathrm{ml}$ Erlenmeyer flask containing $200 \mathrm{ml}$ of potato dextrose broth (PDB) and incubated in dark at $25^{\circ} \mathrm{C} \pm 2{ }^{\circ} \mathrm{C}$ for 21 days under static conditions. Mycelia were harvested and dried at $40^{\circ} \mathrm{C}$ overnight. Culture filtrates were extracted with two volumes (v/v) of ethyl acetate. Dried mycelia were crushed and extracted with five volumes (w/v) of ethyl acetate. The pooled organic extracts were evaporated under reduced pressure at $45^{\circ} \mathrm{C}$ using rotary vacuum evaporator. The dried solid residue obtained was stored at room temperature until assayed.

\section{Human cancer cell lines and culture conditions}

HeLa, HepG2 and PC3 cells were procured from National Centre for Cell Sciences (NCCS), Pune, cultured in Dulbecco's modified Eagle's medium (DMEM), supplemented with 10\% FBS, 100 $\mathrm{U} / \mathrm{ml}$ penicillin and $100 \mathrm{U} / \mathrm{ml}$ of streptomycin in a humidified $5 \% \mathrm{CO}_{2}$ atmosphere at $37^{\circ} \mathrm{C}$.

\section{Invitro cytotoxic activity using MTT [3-(4, 5-Dimethylthiazol-2-yl)-2,5-Diphenyltetrazolium Bromide] assay}

The cytotoxic effect of fungal crude extracts on human cancer cell lines were assayed using MTT assay. Briefly, the cells were seeded in 96 well plates at a density of $1 \mathrm{X} 10^{4}$ cells/well and allowed to adhere. Subsequently, the fungal crude extracts dissolved in $0.4 \%$ DMSO, were added at different concentrations. After $24 \mathrm{~h}$, MTT reagent $(5 \mathrm{mg} / \mathrm{ml}$, SRL) was added and incubated for 3 hours in dark. The blue MTT formozan precipitate was solubilized in DMSO and absorbance was measured at $590 \mathrm{~nm}$ in a multiwell ELISA plate reader (Molecular Devices, USA) scanning spectrophotometer. Cells grown in culture media alone or with appropriate concentrations of DMSO were used as controls.

\section{Cell cycle analysis}

In order to study the effect of Pestalotopsis sp.6 ethyl acetate extract (hereafter referred to as PS6) on cell cycle progression in cancer cells, HeLa cells were seeded in 24-well culture plates at a density of $0.25 \times 10^{6}$ cells/well in DMEM with $10 \%$ FBS and grown for $16 \mathrm{~h}$. The cells were treated with different concentrations of PS6 for $24 \mathrm{~h}$. After treatment, cells were harvested and centrifuged for $5 \mathrm{~min}$ at $1500 \mathrm{X} \mathrm{g}$. The supernatant was removed and the cell pellet was washed twice with ice cold PBS and fixed in ice cold $70 \%(\mathrm{v} / \mathrm{v})$ ethanol overnight at $-20^{\circ} \mathrm{C}$. After washing twice with PBS, the cells were incubated with RNase $(40 \mu \mathrm{g} / \mathrm{ml})$ overnight followed by staining with $10 \mu \mathrm{g} / \mathrm{ml} \mathrm{of}$ propidium iodide (PI). The cells were then analyzed using a FACS Calibur flow cytometer (Becton Dickinson, USA). For each sample, at least 10000 events were acquired. The percentage of cells in the different cell cycle phases ( $\mathrm{sub}-\mathrm{G}_{0} / \mathrm{G}_{1}, \mathrm{G}_{1}, \mathrm{~S}$ and $\mathrm{G}_{2} / \mathrm{M}$ ) was calculated using Flowing software.

\section{DNA fragmentation assay}

DNA fragmentation was visualized following the procedure as described by Gong et al. (1994). Briefly, 3 - 4 X 10\% $/ \mathrm{ml} \mathrm{HeLa} \mathrm{cells} \mathrm{were} \mathrm{cultured} \mathrm{in} 10 \%$ FBS-DMEM medium. The cells were treated with different concentrations of PS6 for $24 \mathrm{~h}$. Treated cells were collected by centrifugation at $1000 \mathrm{X} \mathrm{g}$ for $5 \mathrm{~min}$, washed with $1 \mathrm{ml}$ of $50 \mathrm{mM} \mathrm{PBS}$ and fixed in $70 \%$ (v/v) ice cold ethanol overnight. After fixation, the cells were centrifuged at $1000 \mathrm{Xg}$ for $5 \mathrm{~min}$ and resuspended in $40 \mu \mathrm{l}$ of phosphate citrate buffer (192 parts of $0.2 \mathrm{M} \mathrm{Na}_{2} \mathrm{HPO}_{4}$ and 8 parts of $0.1 \mathrm{M}$ of citric acid, $\mathrm{pH}$ 7.8). After centrifugation at $1000 \mathrm{X}$ g for $5 \mathrm{~min}$, the supernatant was concentrated in speed vac concentrator for $15 \mathrm{~min}$. To this, $3 \mu \mathrm{l}$ of $0.25 \%$ Nonidet P-40 and $3 \mu \mathrm{g}$ of RNase A were added and incubated for $30 \mathrm{~min}$ at $37^{\circ} \mathrm{C}$. $3 \mu \mathrm{g}$ of proteinase $\mathrm{K}$ was further added and the incubation was continued for $30 \mathrm{~min}$ at $37^{\circ} \mathrm{C} .12 \mu \mathrm{l}$ of loading buffer $(0.25 \%$ bromophenol blue, $0.25 \%$ xylene cyanol, $30 \%$ glycerol) was added to each sample and electrophoresed on a $1.6 \%$ agarose gel at 2 $\mathrm{V} / \mathrm{cm}$ for $16 \mathrm{~h}$. $1 \mathrm{~kb}$ DNA ladder was used as reference. DNA was visualized under UV light after staining with ethidium bromide $(5 \mu \mathrm{g} / \mathrm{ml})$. 


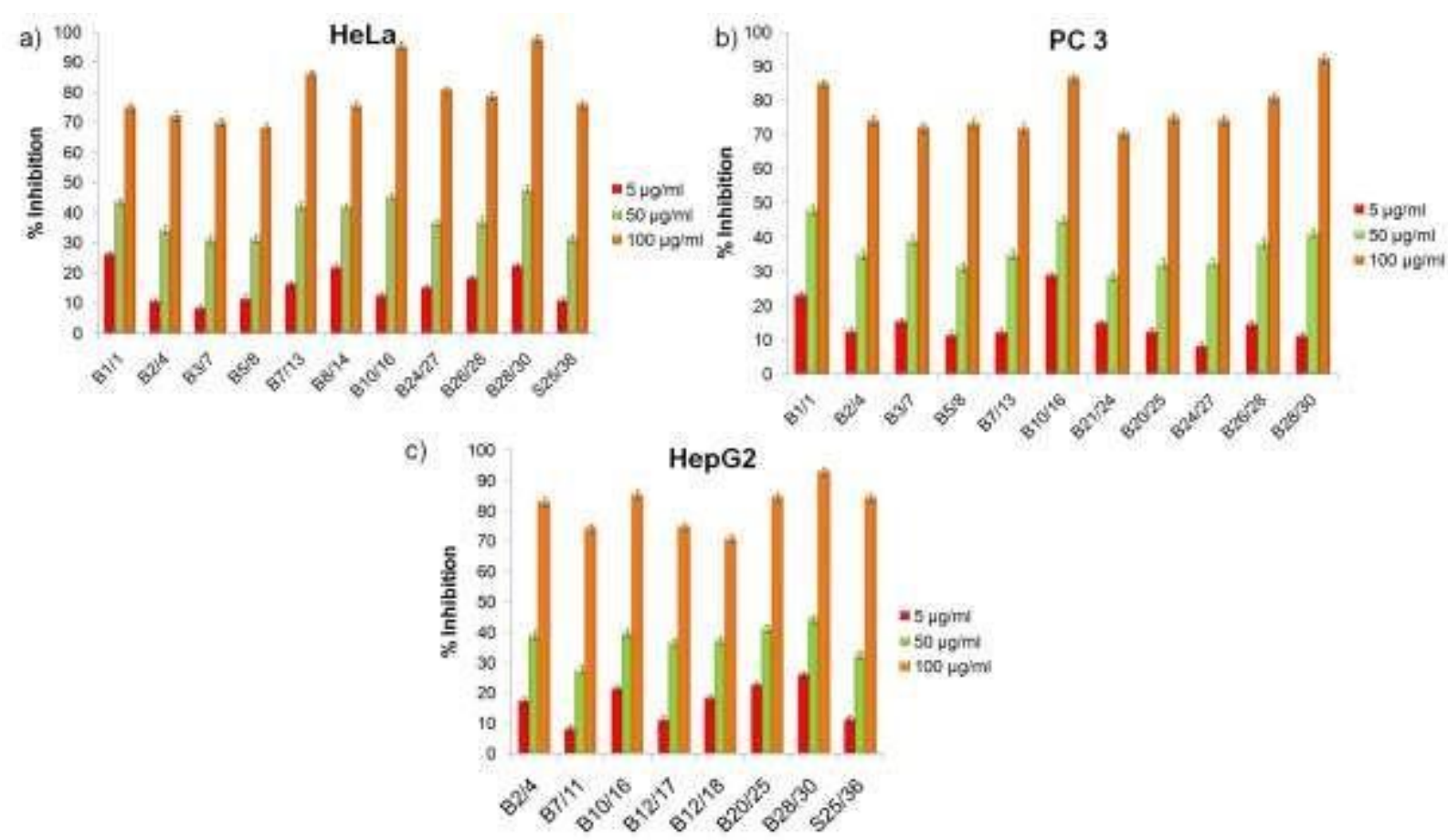

Fig. 2 - In vitro cytotoxic effects of fungal extracts. The cytotoxic activities of ethyl acetate extracts of S. asoca endophytic fungal isolates on HeLa (a), PC3 (b) and HepG2 (c) were assessed by MTT assay.

\section{Analysis of mitochondrial membrane potential ( $\Delta \psi \mathbf{m})$ loss}

The change in the mitochondrial membrane potential was determined using JC- 1 staining. The procedure followed was as described by Cossarizza et al. (1993). Briefly, 2.5 X $10^{5} \mathrm{HeLa}$ cells were cultured per well in 24 well plates and incubated with different concentrations of PS6 for $24 \mathrm{~h}$ in serum containing medium and stained with $2.5 \mu \mathrm{g} / \mathrm{ml}$ of JC- 1 dye at $37^{\circ} \mathrm{C}$ for $15 \mathrm{~min}$. Cells were then washed with ice-cold PBS containing $2 \%(\mathrm{v} / \mathrm{v})$ Bovine serum albumin (BSA) and analyzed immediately by flow cytometry using FACS Calibur flow cytometer (Becton Dickinson, USA) and analyzed using CellQuestTM Pro software using an excitation at $488 \mathrm{~nm}$ and emission at 530, 585 $\mathrm{nm}$. JC-1 monomers emit at $535 \mathrm{~nm}$ (FL-1 channel - green fluorescence) and J aggregates emit at 590 nm (FL-2 channel - red fluorescence). Valinomycin treated cells served as positive control and untreated cells were taken as the negative control.

\section{Results}

\section{Diversity and distribution of endophytic fungi in $S$. asoca}

A total of 381 endophytic fungal isolates were recovered from healthy, asymptomatic stem, bark and leaf segments of $S$. asoca. Analysis of distribution frequencies revealed that the diversity of endophytic fungal population is more in bark tissues of the plant compared to stem and leaf tissues (Table 1). Based on molecular characterization, the fungal isolates were grouped into 37 taxa (Table 2). All fungal isolates belonged to the phylum Ascomycota and these included six classes :

Sordariomycetes, Dothideomycetes, Ascomycetes, Sordariomycetes, Euascomycetes and Eurotiomycetes. Endophytic fungi isolated from $S$. asoca belonged to 22 genera of which the most dominant genera were Camarosporium (CF\%-13), Pestalotiopsis (CF\%-10), Fusarium (CF\%-10) and Phomopsis (CF\%-8.78). Shannon weaver index $(\mathrm{H})$ of the endophytic fungal community associated with $S$. asoca was 2.53. Shannon-Weaver index indicates the diversity of endophytic fungi within the plant. For a community with a species richness (R) of 37 (as obtained in this case), the maximum diversity that can be obtained with an equally distributed population is natural logarithm of $\mathrm{R}$ ( $\ln \mathrm{R}$ ) which is 3.6 in this case. The result indicates the presence of an unevenly distributed diverse endophytic population within the plant. Phylogenetic tree built based on the ITS sequences of 
endophytic fungal isolates is shown in Fig. 1. The data suggests that $S$. asoca possess a diverse endophytic fungal community, with several genera but each containing few members.

\section{Anticancer activity of fungal crude extracts}

Among the 37 fungal organic extracts assessed for cytotoxicity towards three human cancer cell lines, HeLa, HepG2 and PC 3,18 displayed promising cytotoxic activities (IC50<100 $\mu \mathrm{g} / \mathrm{ml}$ ). The crude extracts of 3 isolates, B2/4 (Alternaria porri), B10/16 (Lasiodiplodia theobromae) and B28/30 (Pestalotiopsis sp.6) were cytotoxic towards all three cell lines used (Fig. 2). All Pestalotiopsis species except B16/21 was found to have cytotoxic effects. B1/1 (Pestalotiopsis sp.1) and B7/13 (Pestalotiopsis sp.3) were cytotoxic to HeLa and PC3. B7/11 (Pestalotiopsis sp.2), B12/17 (Pestalotiopsis sp.4) and S25/36 (Pestalotiopsis sp.7) inhibited the proliferation of HepG2 alone. B3/7 (Curvularia sp.1), B5/8 (Bartalinia pondoensis), B24/27 (Fusarium sp.5) and B26/28 (Chaetomium globosum) exhibited significant cytotoxicity towards HeLa and PC3. B20/25 (Colletotrichum gloeosporioides) was cytotoxic to PC3 and HepG2. B8/14 (Fusarium sp. 2) and L15/38 (Neurospora pannonica) were selectively cytotoxic to HeLa. B21/24 (Phoma sp. 1) and B12/18 (Gibberella moniliforme) were cytotoxic to PC3 and HepG2, respectively.

\section{Effect of PS6 on cell cycle progression in HeLa cells}

In order to analyze the effect of PS6 on the cell cycle progression in HeLa cells, the treated cells were stained with propidium iodide. The distributions of cell population across various phases of cell cycle (sub- $\mathrm{G}_{0} / \mathrm{G}_{1}, \mathrm{G}_{1}, \mathrm{~S}$ and $\mathrm{G}_{2} / \mathrm{M}$ ) were studied. An increased accumulation of cells in subG $\mathrm{G}_{0} / \mathrm{G}_{1}$ phase was observed with increasing concentrations of PS6, indicative of cell death. We observed 30.5-85.4\% cells undergoing cell death following treatment with PS6 $(25 \mu \mathrm{g} / \mathrm{ml}$ to 100 $\mu \mathrm{g} / \mathrm{ml}$ ) while only $2.5 \%$ of the untreated control cells were observed in sub- $\mathrm{G}_{0} / \mathrm{G}_{1}$ phase (Fig. 3).

\section{Nuclear DNA fragmentation of HeLa cells by PS6}

DNA fragmentation in an internucleosomal pattern is a major biochemical hallmark of apoptotic cells (Bortner et al. 1995). DNA extracted from PS6 treated HeLa cells formed a characteristic ladder pattern on agarose gel indicative of specific DNA fragmentation (Fig. 4). DNA fragments without the appearance of nonspecific DNA degradation which would otherwise be seen as a smear confirms that PS6 mediated cell death occur via apoptosis and not necrosis in HeLa cells.

\section{Mitochondrial membrane depolarization by PS6}

JC-1 staining was employed to study the involvement of mitochondria in PS6 mediated apoptosis in HeLa cells. Treatment of cells with PS6 for $24 \mathrm{~h}$ disrupted the mitochondrial membrane potential, as evidenced by an increase in the percentage of green fluorescent population from $0.72 \%$ in control cells to $77.6 \%$ in PS6 $(100 \mu \mathrm{g} / \mathrm{ml})$ treated cells (Fig. 5). The results suggest that apoptosis induced in HeLa cell by the extract is associated with changes in mitochondrial membrane potential and that the extract possibly induces apoptotic cell death via intrinsic pathway.

\section{Discussion}

S. asoca is an important medicinal plant indigenous to India, Sri Lanka, Burma and Malaysia. Despite the plant having unique geographic distribution and ethno botanical value, the fungal endophytic population of the plant remains largely underexplored. $S$. asoca extracts have been reported to have antitumor and cytotoxic effects (Varghese et al. 1992). To the best of our knowledge, this work represents the first study to explore the endophytic community of $S$. asoca in search of anticancer metabolites. We isolated 381 endophytic fungi from the asymptomatic tissues of S. asoca which belonged to 37 different taxa. Compared to stem and leaf tissues, bark tissues lodged a diverse endophytic population with 32 different taxa (Table 1). Since bark tissues harbor such a rich endophytic community, it is likely that the fungi recovered from bark tissue produce interesting and useful bioactive compounds. 
a)

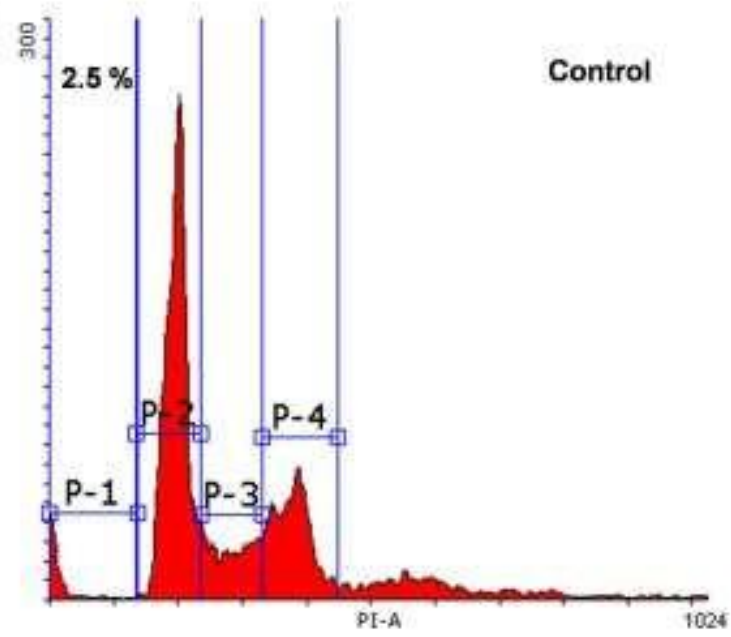

c)

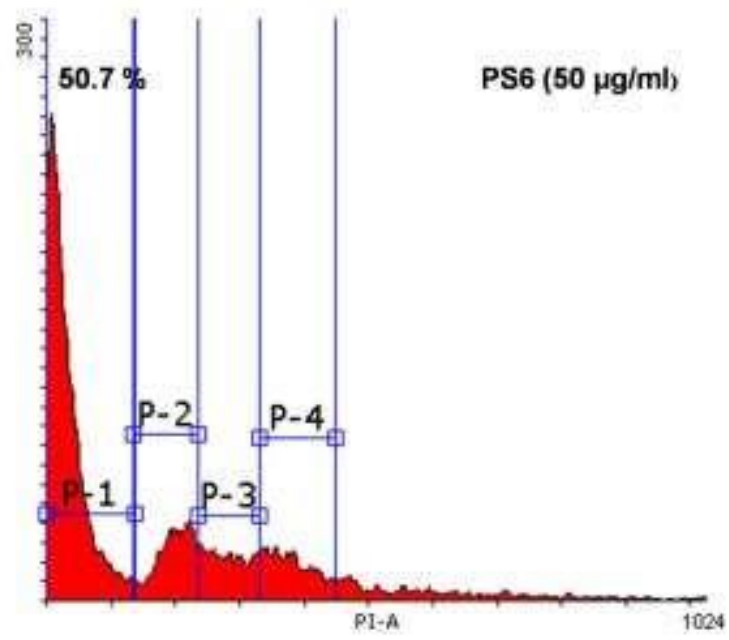

b)

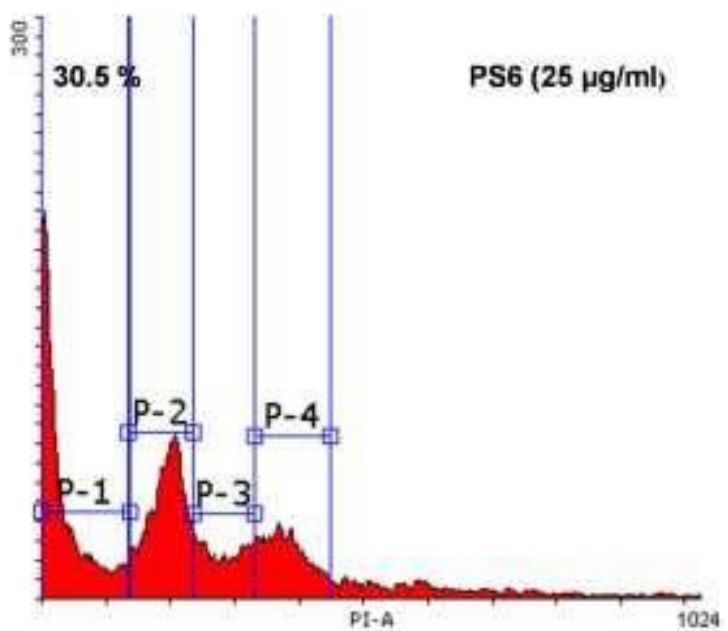

d)

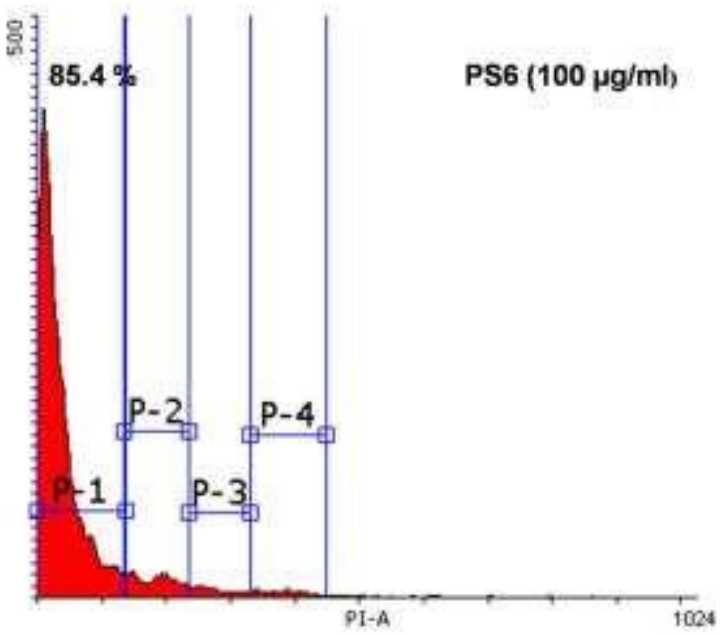

Fig. 3 - The effect of PS6 on cell cycle progression in HeLa cells. HeLa cells were treated with indicated concentrations of PS6 for $24 \mathrm{~h}$, stained with propidium iodide and analyzed by flow cytometry. Sub-Go/G $\mathrm{G}_{1} \mathrm{G}_{1}, \mathrm{~S}$ and $\mathrm{G}_{2} / \mathrm{M}$ phases are represented on the PI histogram as P1, P2, P3 and $\mathrm{P} 4$, respectively.

Table 1 Distribution frequencies of endophytic fungal species within S. asoca.

\begin{tabular}{|c|c|c|c|c|c|}
\hline $\begin{array}{l}\text { Isolate } \\
\text { Code }\end{array}$ & Species & $\begin{array}{l}\text { CF\% } \\
\text { (Bark) }\end{array}$ & $\begin{array}{l}\text { CF\% } \\
\text { (Stem) }\end{array}$ & $\begin{array}{l}\text { CF\% } \\
\text { (Leaf) }\end{array}$ & $\begin{array}{l}\text { CF\% } \\
\text { (Total) }\end{array}$ \\
\hline $\mathrm{B} 1 / 1$ & Pestalotiopsis sp.1 & 5.3 & - & - & 1.8 \\
\hline $\mathrm{B} 1 / 2$ & Fusarium lateritium & 6 & - & - & 2 \\
\hline $\mathrm{B} 1 / 3$ & Cladosporium sp. 1 & 0.3 & - & - & 0.1 \\
\hline $\mathrm{B} 2 / 4$ & Alternaria porri & 0.3 & - & - & 0.1 \\
\hline $\mathrm{B} 2 / 5$ & Sordaria fimicola & 2 & - & - & 0.7 \\
\hline $\mathrm{B} 3 / 6$ & Phomopsis sp.1 & 15 & 1 & 1 & 5.8 \\
\hline $\mathrm{B} 3 / 7$ & Curvularia sp.1 & 0.6 & - & 3 & 1.2 \\
\hline $\mathrm{B} 5 / 8$ & Bartalinia pondoensis & 1.3 & - & - & 0.4 \\
\hline B5/9 & Phomopsis sp .2 & 1 & 0.3 & - & 0.4 \\
\hline $\mathrm{B} 6 / 10$ & Trichoderma atroviride & 2.6 & 0.3 & - & 1 \\
\hline $\mathrm{B} 7 / 11$ & Pestalotiopsis sp. 2 & 1 & - & - & 0.3 \\
\hline $\mathrm{B} 7 / 12$ & Phomopsis sp. 3 & 2.3 & - & - & 0.78 \\
\hline $\mathrm{B} 7 / 13$ & Pestalotiopsis sp. 3 & 1 & - & - & 0.3 \\
\hline $\mathrm{B} 8 / 14$ & Fusarium sp. 2 & 4.3 & 3 & 13 & 6.8 \\
\hline $\mathrm{B} 10 / 16$ & Lasiodiplodia theobromae & 0.3 & - & - & 0.1 \\
\hline $\mathrm{B} 12 / 17$ & Pestalotiopsis sp.4 & 2 & - & - & 0.67 \\
\hline $\mathrm{B} 12 / 18$ & Gibberella moniliforme & 0.6 & - & - & 0.2 \\
\hline
\end{tabular}




\begin{tabular}{|c|c|c|c|c|c|}
\hline $\begin{array}{l}\text { Isolate } \\
\text { Code }\end{array}$ & Species & $\begin{array}{l}\text { CF\% } \\
\text { (Bark) }\end{array}$ & $\begin{array}{l}\text { CF\% } \\
\text { (Stem) }\end{array}$ & $\begin{array}{l}\text { CF\% } \\
\text { (Leaf) }\end{array}$ & $\begin{array}{l}\text { CF\% } \\
\text { (Total) }\end{array}$ \\
\hline $\mathrm{B} 13 / 19$ & Aspergillus niger & 0.3 & - & 0.3 & 0.2 \\
\hline $\mathrm{B} 25 / 20$ & Phomopsis liquidambari & 0.6 & - & 4.7 & 1.8 \\
\hline $\mathrm{B} 16 / 21$ & Pestalotiopsis sp .5 & 3 & - & - & 1 \\
\hline B18/22 & Fusarium sp.4 & 0.3 & - & - & 1 \\
\hline B19/23 & Preussia sp. 1 & 0.6 & - & - & 0.2 \\
\hline B21/24 & Phoma sp. 1 & 0.3 & - & - & 0.1 \\
\hline B21/25 & Colletotrichum gloeosporioides & 0.3 & - & - & 0.1 \\
\hline B22/26 & Fusarium decemcellulare & 0.3 & - & - & 0.1 \\
\hline B24/27 & Fusarium sp. 5 & 0.3 & - & - & 0.1 \\
\hline B26/28 & Chaetomium globosum & 0.3 & - & - & 0.1 \\
\hline B27/29 & Hypocrea rufa & 0.3 & - & - & 0.1 \\
\hline B28/30 & Pestalotiopsis sp .6 & 1.3 & - & - & 0.4 \\
\hline B30/31 & Alternaria sp. 2 & 0.3 & - & - & 0.1 \\
\hline B30/32 & Daldinia sp.1 & 0.6 & - & - & 0.2 \\
\hline $\mathrm{S} 1 / 33$ & Camarosporium brabeji & - & 39 & - & 13 \\
\hline $\mathrm{S} 4 / 34$ & Paecilomyces variotii & - & 0.3 & . & 0.1 \\
\hline $\mathrm{S} 5 / 35$ & Phyllosticta ericarum & - & 0.3 & 0.6 & 0.3 \\
\hline $\mathrm{S} 25 / 36$ & Pestalotiopsis sp. 7 & - & 0.3 & - & 0.1 \\
\hline $\mathrm{L} 2 / 37$ & Colletotrichum sp .2 & - & - & 0.3 & 0.1 \\
\hline $\mathrm{L} 15 / 38$ & Neurospora pannonica & - & - & 0.3 & 0.1 \\
\hline
\end{tabular}

Table 2 Isolate code, closest related species, maximum identities, identification and GenBank accession number of endophytic fungi associated with $S$. asoca.

\begin{tabular}{|c|c|c|c|c|}
\hline $\begin{array}{l}\text { Isolate } \\
\text { Code }\end{array}$ & $\begin{array}{l}\text { Genbank } \\
\text { accession no. }\end{array}$ & Closest related species & Identities (\%) & Identification \\
\hline $\mathrm{B} 1 / 1$ & KC895512 & Pestalotiopsis uvicola (JX875592) & 97 & Pestalotiopsis sp.1 \\
\hline $\mathrm{B} 1 / 2$ & KC895513 & Fusarium lateritium (AY188920) & 99 & Fusarium lateritium \\
\hline $\mathrm{B} 1 / 3$ & KC895514 & Cladosporium sp.(EF02983) & 81 & Cladosporium sp. 1 \\
\hline $\mathrm{B} 2 / 4$ & KC895515 & Alternaria porri(JF710541) & 99 & Alternaria porri \\
\hline $\mathrm{B} 2 / 5$ & KC895516 & Sordaria fimicola(EU818704) & 99 & Sordaria fimicola \\
\hline $\mathrm{B} 3 / 6$ & KC895517 & Phomopsis liquidambaris(KF032029) & 92 & Phomopsis sp.1 \\
\hline $\mathrm{B} 3 / 7$ & KC895518 & Psora decipiens(EF524326) & 94 & Curvularia sp. 1 \\
\hline $\mathrm{B} 5 / 8$ & KC895519 & Bartalinia pondoensis(JX854540) & 99 & Bartalinia pondoensis \\
\hline $\mathrm{B} 5 / 9$ & KC895520 & Phomopsis liquidambaris(KF032029) & 82 & Phomopsis sp .2 \\
\hline $\mathrm{B} 6 / 10$ & KC895521 & Trichoderma atroviridae (KJ174192) & 99 & Trichoderma atroviride \\
\hline $\mathrm{B} 7 / 11$ & KC895522 & Pestalotiopsis uvicola (JX875592) & 97 & Pestalotiopsis sp. 2 \\
\hline $\mathrm{B} 7 / 12$ & KC895523 & Diaporthe sp.7(KC343210) & 83 & Phomopsis sp. 3 \\
\hline $\mathrm{B} 7 / 13$ & KC895524 & Pestalotiopsis uvicola (JX875592) & 99 & Pestalotiopsis sp. 3 \\
\hline $\mathrm{B} 8 / 14$ & KC895525 & Fusarium sp.(EU336988) & 99 & Fusarium sp. 2 \\
\hline B10/16 & KC895526 & Lasiodiplodia theobromae(KJ774056) & 100 & Lasiodiplodia theobromae \\
\hline B12/17 & KC895527 & Pestalotiopsis vismiae(EF055219) & 99 & Pestalotiopsis sp.4 \\
\hline B12/18 & KC895528 & Gibberella moniliformis(JQ363719) & 99 & Gibberella moniliforme \\
\hline B13/19 & KC895529 & Aspergillus niger(KJ778683) & 86 & Aspergillus niger \\
\hline $\mathrm{B} 25 / 20$ & KC895530 & Phomopsis liquidambaris(KF032029) & 100 & Phomopsis liquidambari \\
\hline $\mathrm{B} 16 / 21$ & KC895531 & Pestalotiopsis clavispora(AY924263) & 99 & Pestalotiopsis sp .5 \\
\hline B18/22 & KC895532 & Fusarium lateritium (AY188920) & 97 & Fusarium sp.4 \\
\hline B19/23 & KC895533 & Preussia sp.(EU686933) & 99 & Preussia sp. 1 \\
\hline
\end{tabular}




\begin{tabular}{lllll}
\hline $\begin{array}{l}\text { Isolate } \\
\text { Code }\end{array}$ & $\begin{array}{l}\text { Genbank } \\
\text { accession }\end{array}$ & Closest related species & Identities (\%) & Identification \\
\hline B21/24 & KC895534 & Phoma herbarum(EU823313) & 99 & \\
B21/25 & KC895535 & Colletotrichum gloeosporioides(KJ685391) & 99 & Phoma sp. 1 \\
B22/26 & KC895536 & Fusarium decemcellulare(JX155883) & 99 & Colletotrichum gloeosporioides \\
B24/27 & KC895537 & Fusarium sp.(KF889083) & 99 & Fusarium decemcellulare \\
B26/28 & KC895538 & Chaetomium globosum(DQ003217) & Fusarium sp. 5 \\
B27/29 & KC895539 & Hypocrea sp.(EU622275) & 99 & Chaetomium globosum \\
B28/30 & KC895540 & Pestalotiopsis vismiae(KF990138) & 99 & Hypocrea rufa \\
B30/31 & KC895541 & Alternaria alternata(JF491194) & 99 & Pestalotiopsis sp .6 \\
B30/32 & KC895542 & Daldinia sp.(GU066682) & 99 & Alternaria sp. 2 \\
S1/33 & KC895543 & Camarosporium brabeji(JQ388920) & Daldinia sp.1 \\
S4/34 & KC895544 & Paecilomyces sp.(KF811433) & 99 & Camarosporium brabeji \\
L27/35 & KC895545 & Phyllosticta ericarum(NR111759) & 99 & Paecilomyces variotii \\
S25/36 & KC895546 & Pestalotiopsis neglecta(EF055208) & 99 & Phyllosticta ericarum \\
L2/37 & KC895547 & Colletotrichum siamense(GQ485603) & 97 & Pestalotiopsis sp. 7 \\
L15/38 & KC895548 & Neurospora pannonica(GQ922532) & 99 & Colletotrichum sp .2 \\
\hline
\end{tabular}

\section{PS6 PS6 L $50 \mu \mathrm{gg} / \mathrm{ml} 100 \mathrm{\mu g} / \mathrm{ml}$}

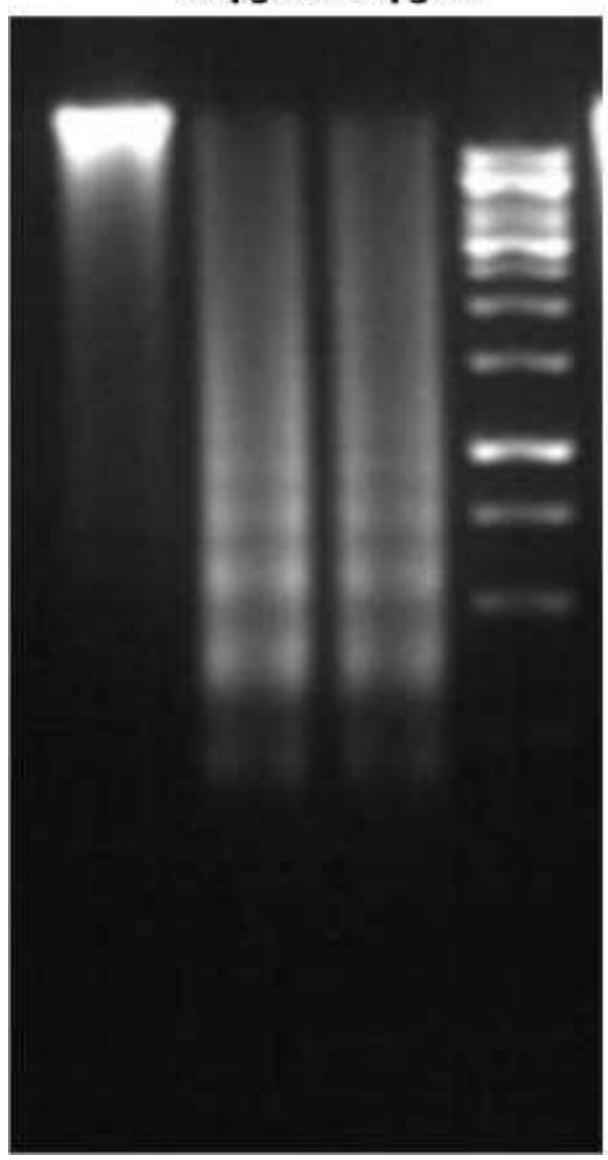

Fig. 4 - Effect of PS6 on DNA fragmentation in HeLa cells. DNA harvested from untreated HeLa cells $-\mathrm{C} \|$ and those treated with indicated concentrations of PS6 for $24 \mathrm{~h}$ were analyzed by electrophoresis on $1.6 \%$ agarose gel. The gel was stained with ethidium bromide and viewed under a UV transilluminator. - Lll represents $1 \mathrm{~kb}$ DNA ladder with a sharp band at $1000 \mathrm{bp}$. 
a)

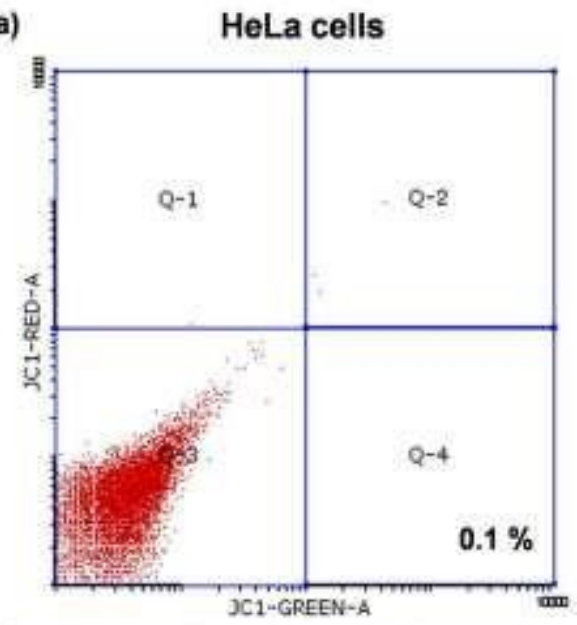

c) HeLa cells + JC-1 + Valinomycin

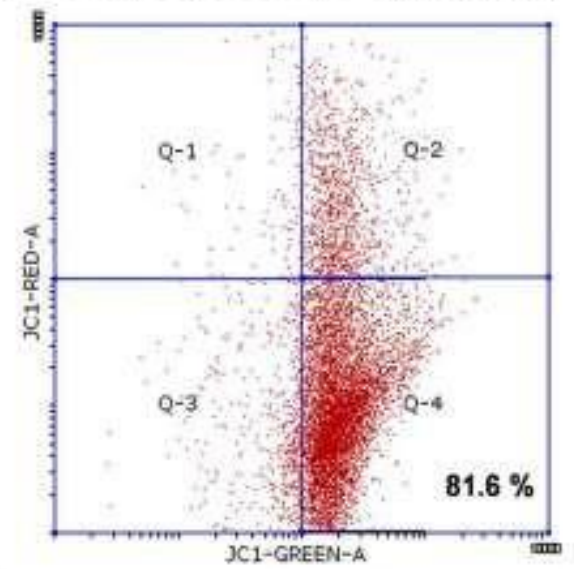

e) HeLa cells + JC-1 + PS6 (50 $\mu \mathrm{g} / \mathrm{ml}$ f

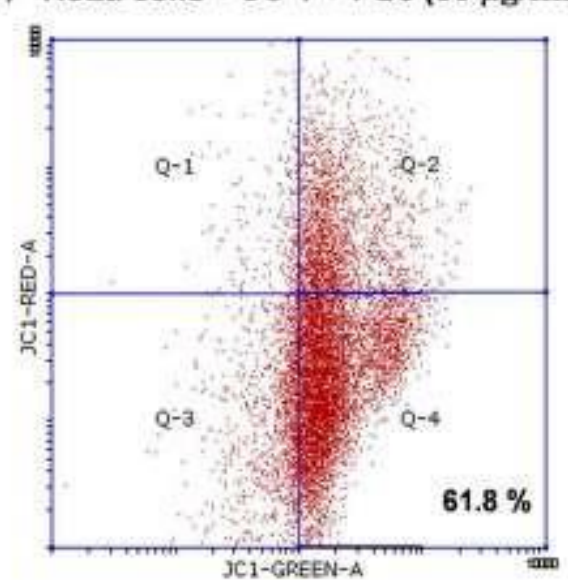

b)

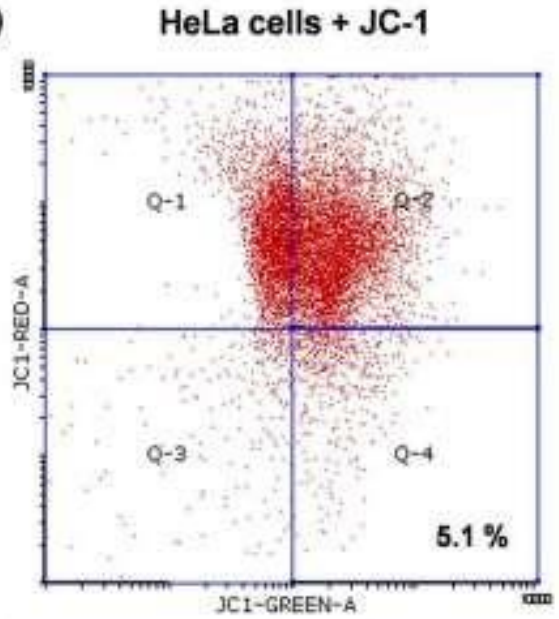

d) HeLa cells + JC-1 + PS6 $(25 \mu \mathrm{g} / \mathrm{ml})$
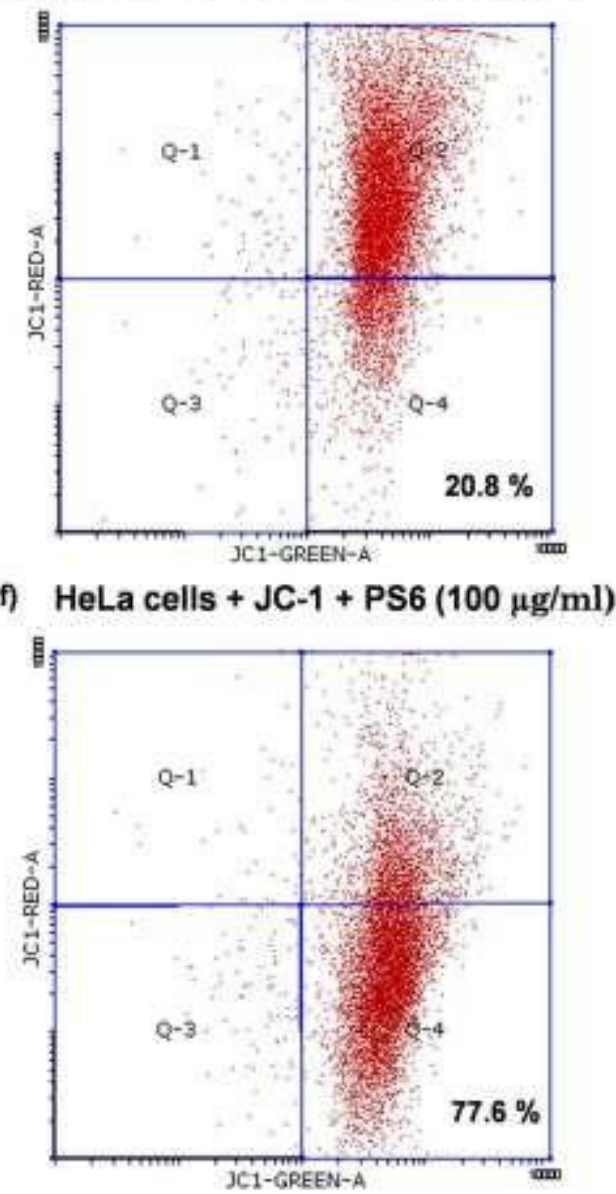

Fig. 5 - Induction of loss of mitochondrial membrane potential in HeLa cells by PS6. Panels a and b represent the experiment controls of untreated cells and untreated cells with JC-1 stain, respectively. Panel $\mathrm{c}$ represents the dot plots of HeLa cells treated with valinomycin used as the positive control and panels d to f represent cells treated with $25 \mu \mathrm{g} / \mathrm{ml}, 50 \mu \mathrm{g} / \mathrm{ml}$ and $100 \mu \mathrm{g} / \mathrm{ml}$ of PS6, respectively.

Among the 37 fungal species obtained from $S$.asoca, 18 were found to have significant antiproliferative and cytotoxic effects (Fig. 2). Majority of the isolates with in vitro growth inhibitory effects on cancer cell lines belonged to the genus Pestalotiopsis. The genus Pestalotiopsis is well known as a potential source of bioactive compounds (Selim et al. 2012). B28/30 (Pestalotiopsis sp.6) exhibited the most promising cytotoxic activity and the cytotoxic effects of PS6 were more pronouncing on HeLa cells. Seven fungal extracts (B7/11, B8/14, B12/17, B12/18, B21/24, S25/36 and L15/38) exhibited cell line specific cytotoxicity. 
Majority of the conventional chemotherapeutic agents kill tumor cells by inducing apoptosis, a highly orchestrated cell death program. Unlike necrosis, apoptosis does not initiate inflammatory response in surrounding tissue and hence is the most desirable target mechanism for the induction of cell death in cancer cells. Mechanism of cell death induction by PS6 was studied in HeLa cells by in vitro assays. PI analysis revealed a concentration dependent cell death induction in HeLa cells by PS6 (Fig. 3). However, a distinct cell cycle arrest was not observed in PS6 treated cells probably due to the rapid activation of apoptotic machinery by the extract. Mitochondria are key mediators of apoptosis. The loss of mitochondrial membrane permeability followed by the release of apoptogenic proteins to the cytosol is a major upstream event in apoptotic pathway (Henry-Mowatt et al. 2004). PS6 treatment initiated mitochondrial membrane depolarization in a dose dependent manner. Taken together, the results indicate the ability of PS6 to induce apoptotic cell death in HeLa cells via mitochondria dependent pathway. Our findings suggest PS6 to be a potential source of anticancer lead molecules. Further work has to be done to isolate the bioactive compound(s) from the fungal crude extracts for anticancer drug development and validation.

\section{Acknowledgements}

We are thankful to the Council of Scientific and Industrial Research (CSIR), Government of India, for financial support in the form of Junior and Senior Research Fellowships.

\section{References}

Aly AH, Debbab A, Kjer J, Proksch P. 2010 - Fungal endophytes from higher plants: a prolific source of phytochemicals and other bioactive natural products. Fungal diversity 41, 1-16.

Bortner CD, Oldenburg NB, Cidlowski JA. 1995 - The role of DNA fragmentation in apoptosis. Trends in cell biology 5, 21-26.

Coates A, Abraham S, Kaye SB, Sowerbutts T, Frewin C, Fox RM, Tattersall MHN. 1983 - On the receiving end-patient perception of the side-effects of cancer chemotherapy. European Journal of Cancer and Clinical Oncology 19, 203-208.

Cossarizza A, Baccaranicontr M, Kalashnikova G, Franceschi C. 1993 - A new method for the cytofluorometric analysis of mitochondrial membrane potential using the J-aggregate forming lipophilic cation 5, 5', 6, 6'-tetrachloro-1, 1', 3, 3'-tetraethylbenzimidazolcarbocyanine iodide (JC-1). Biochemical and biophysical research communications 197, 40-45.

Gong JP, Traganos F, Darzynkiewicz Z. 1994 - A selective procedure for DNA extraction from apoptotic cells applicable for gel electrophoresis and flow cytometry. Analytical biochemistry 218, 314-319.

Henry-Mowatt J, Dive C, Martinou JC, James D. 2004 - Role of mitochondrial membrane permeabilization in apoptosis and cancer. Oncogene 23, 2850-2860.

Persidis A. 1999 - Cancer multidrug resistance. Nature biotechnology 17, 94-95.

Pradhan P, Joseph L, Gupta V, Chulet R, Arya H, Verma R, Bajpai A. 2009 - Saraca asoca (Ashoka): a review. Journal of Chemical and Pharmaceutical Research 1, 62-71.

Selim KA, El-Beih AA, Abdel-Rahman TM, El-Diwany AI. 2012 - Biology of endophytic fungi. Current Research in Environmental \& Applied Mycology 2, 31- 82.

Strobel G, Daisy B. 2003 - Bioprospecting for microbial endophytes and their natural products. Microbiology and Molecular Biology Reviews 67, 491-502.

Tamura K, Dudley J, Nei M, Kumar S. 2013 - MEGA6: molecular evolutionary genetics analysis (MEGA) software version 6.0. Molecular Biology and evolution 30, 2725-2729.

Varghese CD, Nair C, Panikkar KR. 1992 - Potential anticancer activity of Saraca asoca extracts towards transplantable tumours in mice. Indian Journal of Pharmaceutical Sciences 54, 3740.

Verma VC, Kharwar RN, Strobel GA. 2009 - Chemical and functional diversity of natural products from plant associated endophytic fungi. Natural product communications. 4, 1511-1532. 